\title{
Governing Nonhumans: Knowledge, Sanitation and Discipline in the Late 19th and Early 2oth-Century British Milk Trade
}

\begin{abstract}
This article aims to show how elements from the work of Michel Foucault and actornetwork theory can be used as complementary strategies for grasping the constitution of the 'subject' and the 'social' through political technologies. In particular, I try to show that the ontological separation of human from nonhuman and culture from nature is enacted within specific techniques of government, which can therefore be seen as ontological political technologies. This theoretical agenda is worked through empirical case materials in the form of a historical study of the British milk trade, which offers one particular example of how 'the social' has been inscribed within political assemblages. Using documentary analysis I examine the period from around 1890 to 1920 in dairy agriculture, showing how the modern 'social' was enacted within the sanitary drive for clean milk in the towns and cities, and especially within the struggle against zoonotic tuberculosis transmissible through dairy milk. In this sense my analysis is both a contribution to the theorisation of political technologies and an attempt to shift the terms of debate on these technologies substantially towards the ontological politics of knowing, classifying, and policing the human/social vis-à-vis the nonhuman Other.
\end{abstract}

\section{K E YW O R D S}

Actor-network theory; governmentality; milk; nonhumans; ontological politics; political technologies; tuberculosis; zoonoses.

Social science is always founded upon a categorical distinction between the ideality of human intentions and purposes and the object world upon which these work, and which in turn may affect them. There is little room to examine the ways they emerge together in a variety of combinations, or how so-called human agency draws its force by attempting to divert or attach itself to other kinds of energy or logic. (Mitchell, 2002: 29). 


\section{Towards a Symmetrical Governmentality}

This paper draws upon the analytical repertoires of 'governmentality' and 'generalised symmetry'. It attempts to explore their commensurability as strategies for decentring both the human 'subject' and the modern 'social' by tracing their constitution within heterogeneous assemblages, or what I want to call ontological political technologies. ${ }^{\mathrm{I}}$ In this sense it attempts to think through Foucault's (1970; 1984; 199Ib) genealogy of the humanist 'subject' as a contingent effect of historically specific articulations of power/knowledge, and actor-network theory's account of the 'ontological politics' (Mol, I999) continuously enactive of the modern 'social', and to do so simultaneously. ${ }^{2}$ This is neither to deny the specificity of these approaches nor to suggest that either one is reducible to the other, but for now I want to overlook these differences and to focus on the possibilities that emerge if one chooses to foreground their many points of convergence. ${ }^{3}$ This is not of course the first time that Foucault and Latour have been synthesised; but there are diverse ways in which this can be done. ${ }^{4}$ What I want to show in particular is how the resulting mode of analysis enables us to direct our attention to the government of nonhumans, that is, to the political technologies through which heterogeneous entities are managed and how these articulate with, underpin and condition the government of humans in historically specific ways.

Rather than remaining on the plane of abstract theoretical discussion, this agenda is worked through a historical case study of the British milk trade in the late nineteenth and early twentieth centuries. It is empirically grounded in an analysis of documentary sources, consisting primarily of the Journal of the Royal Agricultural Society of England and the Journal of the British Dairy Farmers' Association, which were key journals of the dairying community at this time; along with the Reports of Medical Officers of Health and a range of occasional papers, pamphlets and reports on issues around milk hygiene and the milk supply. As well as utilising these sources empirically I have sought to trace and problematize the organising categories and structures of knowledge which they mediate, and to situate these in relation to contemporary knowledge-practices in order to grasp their role in the historical constitution of subjects, objects and domains. Accordingly, I do not use the historical case simply to 'test' my theoretical argument; nor for that matter is the case study a mere 'illustration' of the theory. Such a rigid separation of theory from analysis would tend to assume a realist ontology contrary to the symmetrical approach here pursued. Instead the historical analysis is used to further develop and refine the theoretical approach already used to inform it. This is consistent with the general principles of grounded theory and I have tried to write in a way that reflects this.

At the core of the following analysis, therefore, is the attempt to show that what we think of as 'the social' is performed or enacted into being within networks of political technologies which inscribe what it is to be human/social through perpetually Othering the nonhuman. Of course the notion of 'enactment' is drawn from the now rather well-known (if not always well understood) actor-network view of the 'social' as

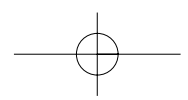


a heterogeneous relational accomplishment (Law, 2004b). ${ }^{5}$ But if we also think of processes of enactment as mediated through specific political technologies, in the Foucauldian sense, then something rather interesting happens to our 'ontological politics'. Just as the analytics of generalised symmetry enable us to trace the heterogeneous assemblages underpinning different modalities of power, even as they emerge ad-hoc from multiple local techniques for the conduct of conduct, so the idea of a 'political technology' of enactment sensitizes us to the mediation of ontological politics through particular techniques of rule. If we can think these elements simultaneously then we can conceive of a 'symmetrical governmentality', alive to the humannonhuman heterogeneity of political technologies, but also attuned to specific modalities of enactment, as mediated by historically specific articulations of power $/ \mathrm{knowl}$ edge. I consider the implications more fully in my conclusion.

In tracing these processes of enactment I focus upon the period from around I890 to 1920 in the British milk trade, which I regard as one particular example of how 'the social' has been inscribed as human through ontological political technologies. Thus I trace how these inscriptions were mediated through the struggle against zoonotic tuberculosis transmissible through dairy milk. Positing zoonotic disease as a form of ontological disordering in its material transgression of the human/animal boundary, I argue that the emergence of this new and dangerous epistemic object, this new hybrid 'agent', led to new and problematic connections between humans and nonhumans. These relations had then to be governed, but the necessary mode of government was itself problematic, for it involved transgressing the established boundaries between public health and agriculture. Previously these had been largely separate domains, structured by a division between the human and the nonhuman, but now the very material connections between these domains were rendered visible and had to be acknowledged in certain kinds of material and knowledge-practices. But these connections were only acknowledged in order to manage their transgression by rendering them governable. I argue that this was an acutely ontological-political accomplishment, enacted through myriad processes of separation of the human from the nonhuman, which were increasingly technoscientific in nature and micro-managed by experts. In this I draw upon Timothy Mitchell's analysis of the pivotal role of 'technopolitics' in the formation of the 'economic' as a distinct sphere in modern Egypt. Mitchell identifies plagues of mosquitoes in their role as vectors of malaria as critical 'agents' in the networks which brought the modern 'economy' into being (2002: 2I). In my account, the problematic 'agency' of milk and tubercular bacilli parallels that of mosquitoes and malaria in Mitchell's analysis, being critical factors in the enactment of the 'social' as an exclusively human domain.

Clearly it is not possible to adequately explicate this whilst remaining at a high level of geographical generalisation; nor do I have the space here for a properly comparative account. I have therefore chosen to focus upon what occurred in Manchester in some detail, so that it effectively forms an extended local example. ${ }^{6}$ I should empha- 
sise that the analytic purpose of this example is intended to be ideographic rather than nomothetic. For whilst I am in agreement with Patrick Joyce (2003: 155) and Simon Gunn (2000) that the changes taking place in Manchester were not isolated developments, it would be beyond the scope of this paper to attempt to fully substantiate this kind of claim. It is anyway not important for the purposes of my argument that the 'representativeness' of this case be established empirically, since its chief purpose is to allow the further exploration of the theoretical considerations outlined above. What I do claim is that the case is illuminating not just for the ways in which political technologies were realised within constellations of competing interests and knowledge claims, but also for the ways in which these shifting networks were variously enabled, disrupted or transformed by the materially heterogeneous connections between nonhumans of diverse kinds.

\section{The Techno-Politics of Tuberculosis}

The last decade of the nineteenth century witnessed a growing anxiety over tuberculosis. Newspapers began to make the link between infant mortality and infected milk on a regular basis, reinforcing a pervasive identification of milk with the disease. ${ }^{7}$ In particular, the belief took hold that dairy milk from the country was responsible for a very significant proportion of the infant mortality from tuberculosis in the towns and cities. ${ }^{8}$ It was this climate of widespread public suspicion of dairy milk that facilitated the development of the sanitary campaign against milk-borne tuberculosis. ${ }^{9}$ Though economic factors also became a driving force for sanitary reform, they could not have driven anything without the political, administrative and discursive articulation of 'clean milk' as a public service, moral duty and national philanthropic 'good'. The emergence of this network shaped economic practice by transforming what was profitable and what was not; thus economic exigency followed rather than determined political, technical and organisational shifts which effectively defined the contours of economic rationality. Indeed the process of concentration of ownership and the emergence of large dairy conglomerates was preceded fully ten years by the beginnings of the development of substantial sanitary regulation of the milk supply (Grigg, I989). This took the form of a growing apparatus of milk inspectors, medical officers of health and local government sanitary officials, engaged in the enforcement of orders enacted under legislative authority conferred by the Board of Agriculture and the Local Government Board (Henry-Rew, I9I4). This in turn brought to a head the tension between rural and urban interests, and particularly between metropolitan veterinary inspectors and medical officers of health on the one hand and dairy farmers and producers' associations on the other.

These groups posited sharply opposing accounts of contamination, accounts which inscribed conflicting moral and sanitary geographies upon the imagined relations between city and country (Sheldon, 1909: 29-30). Dairy farmers typically suggested that it had always been urban milk sellers who were responsible for unclean and

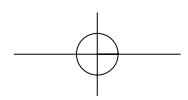


adulterated milk, and that the role of milk-borne infection and bacteria in producing high rates of infant mortality had been grossly exaggerated by the urban authorities in order to divert attention from the squalid conditions in town slums which were the 'real cause' of most tuberculosis. ${ }^{\text {IO }}$ Town sanitary officials meanwhile mustered the resources of the new microbiology and health statistics to sustain the charge that it was the failure of rural producers to fully adopt the measures demanded by sanitary science which was chiefly responsible for flooding the towns with infected milk. ${ }^{\text {II }}$ In this context, the discourse of 'clean milk' represented itself as an attempt to foster an attitude of public service amongst dairy farmers in the interests of urban consumers. Thus clean milk was spoken of as a socially undivided collective 'good', as 'a subject which directly affects every class of a community' (Hay Forbes, I899: 3). In this way contamination, dirt and disease provided the Other against which the sanitary authorities could define their own 'social' and rationalise the extension of the disciplinary mechanisms, political technologies and regimes of surveillance at their disposal (Waddington, 2004: 29). This involved a conflict with farmers, sometimes latent, often explicit, in which different visions of 'civilisation', 'culture' and the 'social' in contradistinction to 'nature' were continuously hammered out. Such conflict is clearest in the almost obsessive concern of the municipal authorities with the inspection of milk coming into the towns by rail from the country, in which the boundaries of the urban area came to signify much more than a purely geographical frontier.

Although there was continuing resistance from farmers to the idea that tuberculosis was zoonotic, the terms of the debate shifted in the years between the mid I880s and 1909, and those who continued to deny the identity of human and bovine tuberculosis became increasingly isolated. The response to zoonotic contagion could not for long be a concerted effort to deny or ignore the transgression it constituted, but had soon to be founded upon a material renegotiation. Thus the ground was laid for the spread of systematic testing of the milk brought into the cities by rail, together with farm inspection and the tuberculin testing of all cattle at farms found to be producing tuberculous milk. Many smaller farmers were reluctant to co-operate with the sanitary measures being imposed upon them, not only because of their lingering scepticism as to the contagiousness of tuberculosis, and especially towards its zoonotic communicability, but also because of their lack of capital. Many were struggling in the face of a rapidly changing industry and could by no means afford to make the necessary investment. ${ }^{12}$ As inspection regimes tightened and sanitary legislation multiplied at an accelerating rate, it was these farmers who frequently bore the brunt of the new disciplinary apparatus, as they found themselves progressively priced out of business by the spiralling demands of 'clean milk' (Grigg, 1989). In this way sanitisation did much to create the conditions in which the larger enterprises could dominate, which in turn fuelled the resistance of smaller farmers to the encroachments of official inspection.

The bacteriological experts were eventually able to gain the advantage of consensus, allowing them to act in a far more concerted and effective manner than their dairy 
farming critics, who were typically isolated and fragmented in comparison and often under-represented in producers' associations. Such consensus was far from quick to emerge however; it was preceded by over a decade of vociferous expert disagreement and rival claims, the beginning of the end of which can be traced to the deliberations of the 1896-98 Royal Commission on Tuberculosis. Previously this disease had been avoided or marginalised in official investigations into cattle diseases and milk hygiene. It was conspicuously absent from all the early legislation against cattle diseases for example, whilst far less common infections such as scarlet fever were included. This was partly because the clinical symptoms of tuberculosis were notoriously hard to identify and difficult to distinguish from various other diseases; thus tuberculosis was something of a grey area until the bacillus was identified microscopically, and even for some time after this. But it was also because, as Keir Waddington (200I: 355) notes, official responses to cattle diseases were organised around a separation of the 'economic' problems of 'agricultural' diseases from the 'social' or 'public health' problems of unclean milk. Tuberculosis flouted this divide materially, and was therefore able to thwart systematic consideration for some quarter of a century after other diseases began to be specifically combated in legislation; it quite literally slipped through the gap created by the separation of human health matters from animal health matters, here a social domain of relations between subjects and there an economic domain of relations between objects.

The inauguration in 1899 of the National Association for the Prevention of Consumption and Other Forms of Tuberculosis was therefore a significant turning point. It was based on the recommendations of the Royal Commission, which were as follows:

Firstly, a systematic inspection of the cows in all dairies and cowsheds by the officers of the local sanitary authority within whose districts the premises were situated. Second, inspection, if requested, of any cows in any dairy or cowshed, wherever situated, by the authorised officers of local authorities within whose district that particular milk is supplied. Third, power for a medical officer of health to suspend the supply of milk from any suspected cow for a limited period pending a veterinary examination. Fourth, power to prohibit the sale of milk from any cow certified by a veterinary surgeon to be actually suffering from tuberculosis, or from such disease of the udder as in his professional judgement renders the animal quite unfit for the supply of wholesome milk. Fifth, the provision of a penalty for supplying milk for sale from any cow having obvious udder disease without the possession by the owner of a certificate that such udder disease is not tubercular. Sixth, the compulsory notification by all owners of cows of any disease in the udder (under a penalty). Seventh, proper separation and isolation of the diseased animals from the healthy ones, and lastly, eighth, the use of tuberculin as a detective agent by farmers and stock owners. (HayForbes, 1899: 7-8)

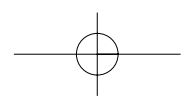


The second of these recommendations was most radical in its implications. ${ }^{\mathrm{I} 3}$ In the context of the vast daily movement of milk by rail from rural producers to urban consumers, which since the railway expansions of the I870s had come to define the industry, this recommendation effectively meant empowering urban authorities to control the milk that was supplied to consumers within their jurisdiction. Seizing upon this, municipal health authorities sought to build an apparatus of sanitary surveillance by constructing a cordon encircling the city, a boundary maintained by the systematic collection and testing of samples of milk and by the inspection of cowsheds and milkshops. These were more than public health measures; they were also political technologies with which to govern the new human-nonhuman relations etched by zoonotic tuberculosis.

\section{The Sanitary City}

The vision of a bounded and sanitised milk-consuming community found one of its earliest and most influential realisations in Manchester. This was the location of the pioneering milk testing and farm inspection regime that came to be known as the 'island system' or 'Manchester method'. ${ }^{4}$ On the face of it this was the product of collaboration between the Medical Officer of Health for the city and Sheridan Delépine, a professor of bacteriology at the University. Delépine was a particularly zealous clean milk campaigner, who undertook to make the resources of his laboratory available to the municipal authorities for the testing of milk samples. Of course Delépine himself was only one element in a complex and heterogeneous network, the effects of which were irreducible to his 'agency'. ${ }^{15} \mathrm{He}$ is nevertheless interesting for my purposes because, not unlike Latour's (1988) Pasteur, he was the most visible human 'actor' standing in for this network, who therefore gave unusually clear expression to its emerging logic; for this reason I will examine his views in some detail.

Delépine proposed a standardised, centralised system of milk testing backed up by legislative authority and linked to regular farm inspections, with punitive powers to seize milk, close milkshops and halt the flow of milk from suspected farms. His view was that it would ideally be desirable for the state to implement this regime in a uniform manner, but frustrated by what he regarded as the government's intransigence on the matter he came up with an alternative strategy, arguing that 'so long as the state remains passive, it is the duty of enlightened principalities to protect themselves against every possible source of disease' (I9I2: 22). But his ambition to see a more general enforcement of the system remained, and he conceived of his method as a strategy for achieving this one town at a time, thus: 'My system has sometimes been called the Island System, but this does not indicate exactly its nature. Its character is one of centrifugal extension by the gradual addition to the area under control of neighbouring areas not yet under control' (I9I2: 30). The effectiveness of this method in Manchester contributed considerable momentum to the campaign against tuberculosis nationally, so that within thirty years the vision of a joined-up web of municipal milk inspec- 
tion underwritten by the state was close to realisation. In what then did the 'island system' consist?

Essentially the innovation of Delépine's method was to draw a sharp division between town and country in sanitary terms and to treat all rural producers as potential suppliers of tuberculous milk, thereby adopting a logic of siege or plague. This inscribed a powerful spatial imaginary, in which the city was counterposed to the country in terms of relative bio-onto-logical security, an imaginary relation which soon became an administrative reality. Previously, although borough authorities had powers to inspect farms and milkshops within their jurisdiction, they had no such powers with regards to farms beyond their sphere of influence. ${ }^{16}$ The Manchester Milk Clauses of 1899, which were based upon the Royal Commission recommendations and which Delépine was instrumental in shaping, transformed this state of affairs dramatically. ${ }^{17}$ From that time forward, samples of milk coming in from various farms in Lancashire, Cheshire, Derby, Stafford and Salop were collected at the railway stations, or elsewhere at the gateways to the city, by the food and drug inspectors. These samples were then sent to the bacteriological laboratory for examination. Any farm found to be sending milk which caused tuberculosis by inoculation was inspected by the veterinary surgeon, who examined all of the cows on the farm and took a sample of milk from each cow having a visibly diseased or suspicious udder. These samples were then tested at the laboratory. Meanwhile the Medical Officer of Health requested the farmer to isolate the cows yielding tuberculous milk, to cease sending the milk of these cows to town, and to have the cows with tuberculous udders slaughtered in the presence of the veterinary surgeon of the Corporation (Delepine, 1912: I4).

Apart from the various processes of testing, both the testing of milk and the testing of cows - made possible by the recent availability of tuberculin as a diagnostic agent, the method was one of disciplinary organisation; it was a system of precise rules designed to engender a certain kind of order (Delepine, I9I2: 23). To illustrate this it is worth quoting Delépine's summary of his method at length:

I. Division of the whole country into a number of well-defined administrative areas, each provided with an efficient staff of veterinary inspectors.

2. Marking and registration of all cattle for purposes of inspection and notification. (This would, of course, mean the inclusion of tuberculosis among the recognised contagious diseases). Systematic periodical inspections of herds and cowsheds within each administrative area. Testing with tuberculin of all cattle.

3. Isolation of all tuberculous cattle. Disinfection of all sheds which have been occupied by tuberculous cattle.

4. Immediate slanghter of all cattle in an advanced state of tuberculosis (including all cases of udder tuberculosis).

5. Fattening of all animals not in an advanced state of tuberculosis for the meat market. All cattle should be slaughtered in public abattoirs, so as to ensure thorough meat inspection. 
6. Compensation during one year or two for losses incurred by owners of cattle, except in cases where there had been gross or culpable neglect. After this transitional period of compensation the presence of a case of advanced tuberculosis in a cowshed ought to render the owner liable to a penalty.

7. Testing of all cattle brought into the area, so as to prevent the introduction of fresh sources of tuberculosis. No cattle above 6 years of age to be imported.

8. All the milk from tuberculous cattle to be boiled before use.

9. Control of all foreign dairy produce, so as to enforce the same standard of purity as in the case of home produce.

IO. To avoid a sudden national depression in the dairy industry, I further suggest that the enforcement of all these measures should not be simultaneously carried out all through the country, but that they should be at first enforced in a certain number of well demarcated administrative areas, to which, year after year, other districts should be added, until the whole country was under administrative control. (Delepine, I9I2: 3I)

This was a system of exacting rules for the conduct of conduct, designed to eliminate the possibility of infection via the establishment of sanitary order, of discipline. It is strikingly reminiscent of Foucault's description of the method typically deployed in order to tackle outbreaks of the plague, with its extraordinary mix of analytical precision, calculation and corporeality (Foucault, I991a: 197). But the deployment of discipline as a means of combating zoonotic disease suggests that these phenomena do not exist on different ontological levels, as modernity maintains, the one being a natural phenomenon and the other a social. On the contrary, both discipline and disease are forms of relation between material configurations and these relations are not incommensurable. In a sense, the Victorian sanitarians and hygienists were better able to see this than we are today, albeit implicitly, for they routinely conflated the social and the natural; they regularly spoke of disease as a form of social disorder, to be fought through social measures. This was not purely figurative. What they were historically unable to see however, and what we are increasingly now beginning to glimpse, is the ontological work required to engender this 'social' in the first place, by extricating it from a nonhuman 'nature' that both encompasses and permeates it (Latour, I993: II).

Between I896 and 1906 alone over 7,000 samples of milk were tested in the Manchester laboratory (Delepine, 1908: 3). The impact of this work was significant and was quantifiable in the statistics that emerged from the testing process:

The effect of inspection has in many cases been remarkable, probably due to the rapid removal from farms liable to inspection of a large number of tuberculous animals. This is the only way in which I can account for the considerable diminution which has taken place in the proportion of tuberculous milk sent from several districts immediately after inspection had begun in these districts. This improvement was quite out of proportion with the number of tuberculous animals actually discovered by the inspector. (Delepine, 1908: 3) 
This amplification of effects is characteristic of the productivity of discipline, the way in which it functions to increase utility (Foucault, I991a: 16). Indeed it is revealing to regard the ensemble of milk testing and farm inspection as an apparatus of surveillance of rural producers by urban sanitary officials. This operated as a mechanism for the production of increased utility, obliging farmers to subject their own practices to discipline without the need for enforcement in a large number of cases; the constant possibility of punitive action was in itself enough to induce the desired change in conduct. In this way fairly limited resources were able to precipitate behavioural change on a wide scale. It was not merely farmers who were governed however, for this was also a means of ontological politics, a disciplinary mode of regulating the boundary between the human and the nonhuman. Thus the cows themselves became a disciplined population, as their potentially zoonotic 'agency', mediated through the flow of tubercular milk and borne along on the currents of commodity-exchange, was carefully governed and made absent.

\section{Othering the Nonhuman}

The regime of milk testing and inspection as it developed in Manchester and other large cities is just one example of how political technologies and forms of discipline have been deployed in the meticulous separation of the human from the nonhuman. One manifestation of this was in changing conceptions of disease. Thus, until the mid I89os there was in almost all public discussion of tuberculosis a fundamental distinction between human-to-human and bovine-to-bovine routes of infection (Waddington, 200I: 355). The possibility of bovine-to-human infection was effectively made unthinkable by sanitary categories structured by a binary division between human and nonhuman routes; thus the specifically transgressive zoonotic logic of tuberculosis was always evaded. In this way the separation of the human 'social' domain from the nonhuman 'natural' domain was inscribed in a consistent separation of public health from agriculture. It would be misleading to say that this was dramatically shattered by the identification of the tubercle bacillus by the German bacteriologist Robert Koch in his laboratory in I882, and by his initial conclusion - which he soon rescinded - that the disease in cattle was the same as that in humans and therefore communicable. ${ }^{18}$ Although Koch only briefly held this view and went on to oppose it vigorously throughout the rest of his career, the spectre it raised, that bovine tuberculosis was transmissible to humans, was nevertheless dramatic in its impact upon existing conceptions of the relationship between public health and agriculture, though this impact was not felt immediately. Rather it took fifteen years of continuous dispute between microbiologists, pathologists, hygienists, clean milk campaigners, farmers' associations, milk sellers, dairy companies, consumers and sanitary officials before the zoonotic communicability of tuberculosis began to emerge as something like a 'fact'. It was never a fact in and of itself, but was made so by being mobilised within an emergent politico-epistemic network.

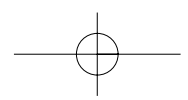


By 1897 this network was durable enough to enable Delépine to argue that the fact 'that tuberculous infection of man by man is more common than infection of man by cattle, is no reason why one should postpone dealing with bovine tuberculosis 'till all human sources of infection have been dealt with' (19I2: 8). This was amongst the earliest criticisms of the rationale underpinning the separation of public health from agriculture, which made it difficult to acknowledge that the dynamics of bovine-tobovine infection and those of human-to-human infection were materially interrelated through the circulation of milk:

Although the sanitarian and the agriculturalist have a common interest against tuberculosis, the special methods which afford a measure of protection to man are quite insufficient to protect cattle against the spread of the disease. The reverse is not true, for if bovine tuberculosis were stamped out by general measures the sanitarian would have nothing to fear from tuberculosis of cattle. The eradication of bovine tuberculosis is, therefore, a subject in which the hygienist is keenly interested. (Delepine, I9I2: 9)

Such reasoning lay behind the gradual erosion of the distinction between public health sanitation and agricultural disease prevention which was taking place at that time. This was both a response to the new human-nonhuman relations inscribed by zoonotic tuberculosis and an attempt to manage those relations, to govern them both materially and ontologically. It marked a change of 'method assemblage' (Law, 2004a: I6I) rather than a fundamental ontological transformation. Thus, whereas previously the human/nonhuman dichotomy had been enacted within the distinction between public health and agriculture, this was now increasingly problematised materially and had therefore to be re-articulated in the face of the new hybrid agent made visible by the microscope. Certain entities such as tubercle bacilli had become 'obligatory passage points' established by the emerging networks of technical knowledge, and which only technical knowledge-practices could now negotiate. ${ }^{19}$ Hence the work of governing these nonhumans was increasingly undertaken within these practices, which in this sense were involved in the perpetual making-absent of their own conditions of necessity.

An example which nicely illustrates this is the changing practice of milk testing in Manchester. Until the I89os the favoured method in use for protecting consumers from infected milk was by 'the production of increased resistance to infection'. This meant improvements in housing, nutrition, clean water, air quality, hygiene and drainage, which it was believed would increase people's resistance to tuberculosis, for it was known that the weak, the undernourished, and those living in dirty and overcrowded conditions, were more likely to contract the disease. ${ }^{20}$ This approach was typical of 'social' sanitation, which sought to control 'natural' forces through the manipulation of 'social' conditions (Joyce, 2003: 63, I7I). Interestingly 'the social' in this strategy was a rather inclusive category, encompassing an array of material entities and human-nonhuman assemblages, and even aspects of the 'natural' environment, in- 
deed everything perceived to be a 'vital' condition for human beings to function 'normally' as 'vital' subjects of modern urban society (Otter, 2006). In other words the 'social' of public health sanitation was a function of a certain kind of governmentality. What it did not include however were the human-nonhuman relations of agricultural production and the human-nonhuman connections inscribed by zoonotic infection; these hybrids were definitely not 'social. ${ }^{21}$

As the anxiety associated with the question of milk-borne tuberculosis grew, the sufficiency of 'social' sanitation began to be questioned. It was criticised for its failure to tackle the disease 'at source' due to its separation of 'public health' from 'agricultural' measures. The 'source' of the problem was increasingly located within the nonhuman and the 'natural', and especially in the unregulated passage from the nonhuman to the human, rather than within the human social domain. Thus, whilst the 'social' approach took the autonomy of 'the social' for granted, this was precisely what was under threat from zoonotic disorder and had to be actively entrenched by boundary-making practices; the various methods of testing milk for tuberculosis were responses to this problem. There were three types of tests, each with very different implications:

Firstly there were microscopic tests. These involved examining tiny samples of milk under a microscope for tubercular bacilli. Due to the central role of the microscope in the initial identification of tuberculosis this was often assumed to be the most 'scientific' and reliable test. In fact it was the least reliable, as the bacilli could be extremely difficult to detect in a sample of milk if they were as yet small in number. ${ }^{22}$ This was compounded by the fact that the great majority of the milk being transported into cities was mixed milk, that is, it was the milk of many cows mixed together; hence the chances of detecting the bacilli in any given sample were minute.

The second type of test was the cultivation test. This involved encouraging the growth of bacteria from samples of milk placed on agar jelly. The rate of multiplication of the bacteria allowed the original numbers of bacteria in the sample to be calculated, which provided a measure of the relative cleanliness of the milk. These cultivation tests, the numerous tabulated results of which were a staple feature of the reports of the Medical Officers of Health for Manchester and Salford, were actually more relevant to the campaign for 'clean milk' than to measures to secure milk free from tuberculosis. ${ }^{23}$ Along with tests which made use of a centrifuge to separate out and measure the amount of 'dirt' in the milk - which formed a sediment or 'slime' consisting of cells from the cow's udder; hairs from the cow's skin; matter from food, dung or litter clinging to the skin of the cow; worms, insects and arachnids; yeasts and moulds - these bacterial tests were really a test of the standards of hygiene obtaining during the processes of transportation and storage of the milk, hence a test of the conduct of the humans involved in conveying the milk, rather than of the diseased or healthy status of the cow. ${ }^{24}$ This method of testing was therefore of a piece with a slightly different set of concerns, with a somewhat longer history, as to the 'purity' or 'cleanliness' of milk, variously defined. ${ }^{25}$ They were part of a 'social' public health

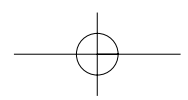


strategy ill equipped to meet the challenge posed by the emergence of milk as a medium of zoonotic contagion.

The third kind of tests were inoculation tests, which involved injecting a small quantity of milk into a nonhuman animal of some kind, usually a guinea pig, and then simply waiting to see whether the animal developed symptoms of tuberculosis (Delepine, 1908: 3). This was the most reliable method, but it could take up to three weeks to obtain a clear result, which militated against its preventive use. Hence even this kind of test was not a panacea for the problem of how to obtain a milk supply free from tuberculosis. ${ }^{26}$ Indeed no form of laboratory testing could in and of itself achieve the desired result. ${ }^{27}$ When combined however with an additional apparatus of surveillance, in the form of regular farm inspections and tuberculin testing of suspected herds, inoculation testing proved highly effective, for it was part of an approach which for the first time bridged the gap between municipal public health and agricultural disease prevention. ${ }^{28}$ Thus, the emergence of zoonotic tuberculosis led to the development of a form of sanitary organisation which was no longer 'social' in the earlier sense, for it no longer operated on the prior assumption of a separate human 'social' but upon a heterogeneous human-nonhuman collective, from which it laboured to engineer a separate human 'social' and to make this 'social' appear as autonomous and exclusively human as ever.

These tests were undertaken by an ascendant class of scientific professionals employed by municipal authorities and consisting of food and drug inspectors, medical officers of health, pathologists and bacteriologists. Each kind of test was more than a technical practice, for it inscribed a specific vision of agency, of ontology, of subject and object, social and natural, with commensurate attributions of responsibility, of justice and morality. In this way the laboratories where the tests were conducted became key sites of ontological production in which modernity was perpetually engineered (Latour, 1983). Thus the testing regimes were not merely means to ensure the 'purity' of the product or the 'safety' of the public, but were also political technologies for the policing of the unstable boundary between the human and the nonhuman, between 'culture' and 'nature'; they were at once disciplinary techniques and boundary-making practices.

\section{Conclusion: Orchestrating 'the Social'}

The period from around I890 to 1920 witnessed some important changes in the sanitary regulation of the British milk trade; at the centre of these changes was a shift in the relationship between urban public health and agriculture. This was precipitated by the problem of zoonotic tuberculosis conveyed into the cities by milk, which had wider significance in terms of how the relationship between the human and the nonhuman was governed within the political technologies of sanitary discipline. The earlier period had seen a separation of the human/social from the nonhuman/natural inscribed within the dislocation of 'public health' sanitation from 'agricultural' dis- 
ease prevention. This separation was gradually undermined by the emergence of a network assemblage which gave increasing facticity to the claim that tuberculosis was the same disease in humans as in cattle, and transmissible from one to the other through the medium of infected milk. Thus the zoonotic 'agency' which emerged from a network of heterogeneous relations between the microscope, the bacilli, the bodies of the infected cows and their susceptibility to the disease, the tissues and organs of laboratory animals such as guinea pigs, and the organic properties of the milk itself, led to the emergence of new human-nonhuman relations, which had then to be governed before the disorder could be managed. This network was necessarily contingent, messy and uncertain; hence it was more than a decade after the initial identification of tuberculosis before it was able to coalesce into an effective historical conjuncture. The intervening years were characterised by widespread epistemic conflict, expert disagreement, paradigm instability and resistance from farmers.

There was a spatial dimension to this, as the city was increasingly imagined in clean milk discourse as a besieged island of bio-onto-logical security, as an enclave of 'culture' surrounded by the insecurities of a zoonotic 'nature'. This was materially enacted with the construction of a regime of milk testing and farm inspection, which effectively formed a sanitary cordon around the city, and which involved extensive surveillance of farming practices by urban sanitary authorities. Thus these practices on the boundary between the human and the nonhuman were both distanced from and disciplined by 'the social city'. This discipline at a distance was also a means of surveillance of the cows themselves, a political technology by means of which their disruptive 'agency', their capacity to make a difference, was contained, managed, and as far as possible made invisible through the imposition of sanitary discipline as a form of ontological ordering. Modernist separation and purity was thereby re-established against the mixture and impurity of the disease. Of course the nonhuman 'agency' in question was itself an emergent property of a network encompassing the laboratory and the microscope as well as the cow (Callon, 1986). The imposition of discipline meant constructing a different network from these elements which re-articulated them. Thus the inoculation testing of milk, the tuberculin testing of cows, the inspection of farms and the isolation and slaughter of diseased animals, were not just sanitary practices or public health measures, but were also ontological political technologies, through which the human-nonhuman connections inscribed by zoonotic tuberculosis were both governed and made absent as a condition of modernity.

Returning then to the theoretical synthesis discussed in the introduction to this paper, what I want to suggest, in the light of this analysis, is that the modalities of power/knowledge traced by Foucault and the processes of enactment analysed by actor-network theory are inextricably intertwined: Modern governmentality defines a circumscribed sphere of action where power is both present and legitimate, that is the realm of 'politics'; whilst the field of power itself is far wider, deeper, and subtler, invested within knowledges, material processes, disciplines and technologies as much as in the explicit machinery of politics. Scientific expertise, on the other hand, defines

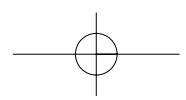


a sphere of action where politics is absent, where knowledge is pure, that is the realm of 'truth'; whilst the technologies of power not only encircle this sphere but are intrinsic to it. Thus the interpenetration of discourses of truth and technologies of power cuts deeply, and it cuts both ways. But what does this tell us about the analytical advantages of combining 'governmentality' and 'generalised symmetry'? It tells us firstly that the 'ontological politics' of ANT is a necessary corrective to the relative blindness of Foucauldian approaches to the nonhuman elements in political assemblages. But it also suggests that it is unwarranted to view power chiefly as an effect or emergent property of networks, rather than the means of their production. Power, after all, is productive, and particularly modern disciplinary power. It is by no means clear that this form of power observes any ontological distinction between human and nonhuman in what Foucault refers to as its 'art of distributions' (Foucault, 1991a: I42-3). Rather it seems to produce this distinction through its own techniques, which arise ad-hoc in the context of various disciplinary practices before being diffused. Hence such techniques must themselves be seen as generative of the principles of ontological differentiation, of subject and object, culture and nature, human and nonhuman.

There is clearly no case then for analytically privileging either network assemblages or political apparatuses; the key thing is to recognise their simultaneity, their mutual constitution, in situations of practice. The networks are themselves political technologies, they are the machinery of power, but power in turn continually produces the networks. As I hope to have shown, some of the problems of 'generalised symmetry' can therefore be mitigated by the integration of an analytics of 'governmentality' within a broadly ANT approach. In particular, the hybrid concept of ontological political technologies makes it possible to trace the mutual constitution of 'the social' and the human 'subject' within heterogeneous configurations of power/knowledge and materiality, encompassing political rationalities as well as ontological discourses, nonhuman entities as well as disciplinary technologies. From this point of view, 'the social' denotes more than just a heterogeneous relational accomplishment, for it is also what emerges from a historically specific ensemble of political technologies or techniques of government. But these political technologies have to be grasped symmetrically, as both methods of rule and as ontological inscription devices which enact the modern 'social' as a domain of human 'subjects'. Of course their main rationale is the disciplining of human bodies and populations, but in and through this they also perform the distinction between what lies within the domain of the human, the social and the cultural, and what does not. This ontological politics is the condition of possibility of politics proper; its object is the entrenchment and perpetual reproduction of a particular ontological division of the world, which in turn constitutes the human as a certain kind of 'subject' amenable to specific technologies of rule. It transpires therefore that 'the social' is what is made to emerge as governable from a heterogeneous humannonhuman collective, by the ensemble of political technologies which constitutes a regime of governmentality. 


\section{Notes}

I Without wanting to get bogged down in too many definitions, it is necessary to the argument that my usage of certain concepts be clarified: Governmentality then as I understand it is essentially a genealogy of power, directing attention not towards relations of force between what are taken to be pre-existing, given, known social objects and knowing subjects, but instead towards how these configurations of objects and subjects of power-knowledge are brought into being through multiple, overlapping and contingent processes. Thus governmentality takes as its object of enquiry not power as such, viewed as a brute force of coercion between separate sovereign entities, but rather the conditions of possibility of particular modalities of power understood as organised around historically specific rationalities. This is close to an ANT view of power, except that the latter attempts to explain power in terms of the enactments of ontology, whereas the study of governmentality critically reconstructs the rationalities of power. Generalised symmetry is very nearly a synonym for actornetwork theory, but one that emphasises its commitment to a consistently non-dualist and agnostic approach when it comes to what is 'social' and what is 'natural', hence also to what is 'subjective' and what is 'objective'; a symmetrical approach endeavours to explain all phenomena in similar terms. From this point of view, the separation of 'culture' from 'nature' emerges not as an ontological given, but as the product of modernity's ongoing work of purification, which perpetually inscribes this dichotomy upon the world as a condition of its own coherence and authority.

2 Ontological politics (Mol, 1999) is a very useful ANT concept which emphasises the political nature of ontological ordering processes. If ontological identity is a matter of relational enactment and attribution, as ANT suggests, if realities are performed, rather than something inhering in the essential 'nature' of things, then these identities need to be viewed not in terms of what they are, but rather what they $d o$, or what they make possible. To my mind this is one of ANT's sharpest contributions to the theorisation of power, approaching something like a 'critical' position but without the realist conceptual architecture of critique.

3 I do not wish to detract from the central argument of the paper by cataloguing the obstacles to any Foucault-ANT synthesis or its various limitations. It should be acknowledged however that these two approaches do involve somewhat different conceptions of 'the social' and of 'politics', which it is not unproblematic to combine. I propose one possible solution in my conclusion.

4 See for example Gavin Kendall and Mike Michael (1998). This article is excellent on some of the strengths of Foucault's approach to the ad-hoc emergence of networks, as well as on the difference between 'technique and 'technology'.

5 For an excellent account of enactment see Law (2004).

6 Manchester was a very large city at the end of the igth century with around 900,0oo milk consumers. A century previously it had depended upon supplies brought along the Bridgewater canal by cart or produced within the city. Its consumption in I897 was about I4.7 million gallons per annum, only about I6 gallons a head or under 2.46 pints a week. The supply was mainly composed of milk brought by rail from Cheshire, Derby, Stafford, Lancashire and Salop, and delivered to stations in and within a 4 mile radius of the city amounting to I0.36 million gallons annually. Cows kept in the same area produced 2.8 million gallons, and a further supply of I.5 million was brought in by cart from a radius of about eight miles.

7 'A great deal has been written in the press about milk being disastrous to infantile life in large cen- 
tres' (author unattributed, Journal of the BDFA XXXIII, 1909: 73).

8 Savage writes:

It is unnecessary to offer proof of the connection, as the evidence is abundant, convincing, and accessible. At least Io percent of average mixed milk samples contain tubercle bacilli, while probably about 15 to 20 percent of the tuberculosis in children is due to milk infection. (I9I7: pages unnumbered)

9 See Nuttall after Sadler (1909: 73). See also Horner (1909: 36).

Io According to Sheldon:

The avowed object of such legislation as we are led to expect is, primarily, the protection of infant life in towns against tuberculosis, which is alleged to come from the country. But have the officials concerned in it solved the problem which underlies the infection to which these town bred children are so unfortunately liable? Have they analysed the air of the great towns, and especially of the slums therein contained? Were they to devote to this potent source of contamination one half of the scrutiny they have given to milk, it is more than probable that their eyes would be opened to a different phase of the question... this infectious air will, when adequately investigated, be found to be more in fault than any supply of milk from the country. (Sheldon, 1909: 29)

II 'In this country Woodhead, McFadyean and I have for over twenty years collected evidence and conducted investigations indicating that bovine tuberculosis is very prevalent in Great Britain and is a danger to human health' (Delepine, I9I2: 4).

I2 The attitude of sanitary officials to this predicament was typically unsympathetic: 'To eradicate tuberculosis is expensive, but on economic grounds and merely from the point of view of the agricultural community, it pays to spend money for this purpose' (Savage, I9I7: pages unnumbered).

I3 'The legislation that permits one authority to enter upon a dairy premises situate in the area of another and sometimes distant authority caused a great outcry, and a very determined stand was made against it' (Davies, 1906: 87).

I4 The Manchester Milk Clauses of 1899 were in fact a few years behind Glasgow's adoption of similar measures, reflecting Scotland's consistent position at the forefront of major reforms of the milk industry, such as milk recording. I have focussed upon Manchester on the grounds that although Manchester was not chronologically the first city in Britain to introduce systematic milk testing linked to farm inspection, it developed by far the most influential model of this system. Glasgow was an advanced but isolated development, whereas Manchester, just a few years later, provided the catalyst for the adoption of similar measures in every city:

Glasgow was about the first local authority to acquire powers to inspect dairies and cattle outside its own area from which milk was sent to that city. Manchester quickly followed, and it was over the Manchester Bill that the chief battle was fought. (Davies, 1906: 86)

I5 For a seminal example of ANT's anti-heroic approach to the network construction of individual scientific 'pioneers' see Bruno Latour's (1988) The Pasteurization of France.

I6 Delepine (1912: I3) writes:

The Borough authorities have for a long time been able to control the farms and dairies within its boundaries, but up to I899 were unable to influence adequately the rural districts from which the bulk of the milk supply was derived. Our preliminary investigations, conducted before that date, have shown that the rural supply was highly infected. 
I7 'Manchester Method (Niven 1899) - The method of control at present in use in Manchester was devised for the purpose of protecting the town against the importation of tuberculous milk from the country' (Delepine, 1912: 13).

I8 Hay Forbes (I899: 4) writes:

Let us for a moment enquire as to the direct cause of tuberculosis, and when we have determined that, we will be in a better position to take note of any accessory causes. In 1883 Dr. Robert Koch discovered that tuberculosis was caused by the presence of a very minute germ or fungus, which under the microscope has the appearance of a "little rod" with rounded ends and is striped on its surface. This, when it attacks the tissues of the body, develops small round nodules or "tubercles". These germs or tubercle bacilli will only grow under certain conditions.

I9 Obligatory passage point is an ANT concept intended to capture the way in which certain elements in a network/assemblage become so durable and entrenched that they are able to circumscribe the possibilities of further network assemblage; they become 'hard' nodes or indispensable configurations in the network which 'narrow' the channels through which other agents may pass. This explains the apparent anteriority of certain 'realities'.

20 According to Delepine (1912: 13):

It has been suggested that resistance to tuberculous infection could be so increased by improved social conditions (including good feeding, proper housing, and good sanitation) as to render the chances of infection slight. It is quite true that poor, weak, ill-fed individuals, crowded in unhealthy dwellings, are much more liable to suffer from infection than others; but I do not believe that simple sanitary and hygienic measures - valuable adjuncts though they are - can overcome the danger of infection by massive doses of infecting material, and, more especially, that infants could be protected in this way from the effects of feeding on tuberculous milk.

2I Although it would be beyond the scope of this article to engage with it substantially, there is an extensive literature dealing with the significance of the 'animal' nonhuman in modernity. Just a few key texts from this literature include Adrian Franklin (1999), James Serpell (1996), and Arluke and Sanders (1996). A somewhat different but related approach to this question is the feminist technoscience analysis of Donna Haraway (1991; 1992; 2008).

22 'Much confidence has been placed in microscopical examination ... But when the bacilli are few the labour needed for their detection is so considerable as to render the thing impracticable' (Delepine, I9I2: II).

23 Delepine (I9I2: I2) states that:

As a matter of fact, tubercular milk is often remarkably free from bacteria capable of growing rapidly on gelatine or agar media. This kind of bacterial standard is absolutely useless for the purpose of preventing the sale of tuberculous milk.

24 According to Delepine (I9I2: II):

The importance attached by many observers and administrators to the number of bacteria present in milk may be justified if the cultivation method is only used for the purpose of ascertaining how the milk has been handled, how long and at what temperature it has been kept. But unless the milk is tested by cultivation immediately after it has left the cow, this method does not give any material information as to the state of the cow.

25 Savage (I917: pages unnumbered) writes: 
Bacteriological standards as a basis upon which to accept or reject milk are undesirable, but they are invaluable as a basis for classifying the milk producers and for judging the cleanliness of production. Those producers whose milk contains abundance of bacteria require to be promptly visited, their methods of milking inquired into and their cowshed conditions inspected. In this way the producers of the dirtiest milk can be rapidly ascertained, and if legal powers are available the conditions altered and brought up to the standard of others.

26 Delepine (I9I2: I2) states:

When proper care is exercised this method yields very reliable results, its great defect is that it cannot yield these results in less than ten days, and that on average about three weeks are necessary to ensure, for practical purposes, the reliability of negative results.

27 According to Delepine (I9I2: I2):

The methods of testing which I have described are, I believe, the only ones that have been used extensively up to the present day. I think I am justified in saying that they are all unsatisfactory when employed for the purpose of controlling directly the sale of milk... This difficulty may, however, be partly overcome by a combination of the testing of milk with the inspection of farms. I will refer to this plan later on when giving an account of the work done in Manchester.

28 Delepine (I9I2: I3) states:

The magnitude of the work is clearly shown by the statistics which have been collected during the past thirty years, and which prove the great prevalence and wide distribution of bovine tuberculosis. It is also clearly indicated by the results which we have obtained in Manchester in the course of the last fourteen years by the application of a method of control which may be considered as forming a link between municipal and agricultural methods.

\section{References}

Arluke, Arnold and Clinton Sanders (1996) Regarding Animals. Philadelphia: Temple University Press.

Callon, Michel (1986) 'Some Elements of a Sociology of Translation: Domestication of the Scallops and the Fisherman of St. Brieuc Bay', pp. I96-233 in John Law (ed) Power, Action and Belief: A New Sociology of Knowledge. London: Routledge and Kegan Paul.

Davies, C. B. (1906) 'Legislation Affecting the British Farmer', Journal of the BDFA XX.

Delepine, Sheridan (1908) Pathogenic Properties of and Amount of Dirt contained in the Milk supplied to the Town of Manchester during the Ten Years 1897 to 1906 inclusive. Manchester: Sheratt and Hughes.

Delepine, Sheridan (I9I2) 'Tuberculosis and the Milk Supply', paper presented to the Association of Medical Officers of Health Annual Meeting in Edinburgh, October I3, I9II; published in the Journal of Meat and Milk Hygiene, March I9I2; filed as a paper in the Delepine Collection, John Rylands University of Manchester Library.

Franklin, Adrian (1999) Animals and Modern Cultures: A Sociology of Human-Animal Relations in Modernity. London: Sage.

Foucault, Michel (I970) The Order of Things: An Archaeology of the Human Sciences. London: Tavistock.

Foucault, Michel (I984) 'Truth and Power', pp. 5I-75 in Paul Rabinow (ed) The Foucault Reader. London: Penguin.

Foucault, Michel (1991a) Discipline and Punish: The Birth of the Prison. London: Penguin. 
Foucault, Michel (I99Ib) 'Governmentality', pp. 87-IO4 in Graham Burchell, Colin Gordon and Peter Miller (eds) The Foucault Effect: Studies in Governmentality. Hemel Hempstead: Harvester Wheatsheaf. Grigg, David (1989) English Agriculture: An Historical Perspective. Oxford: Blackwell.

Gunn, Simon (2000) The Public Culture of the Victorian Middle-Class: Ritual and Authority in the English

Industrial City I840-19I4. Manchester: Manchester University Press.

Haraway, Donna (I99I) Simians, Cyborgs, and Women. London: Free Association Books.

Haraway, Donna (1992) Primate Visions: Gender, Race and Nature in the World of Modern Science. London: Verso.

Haraway, Donna (2008) When Species Meet (Posthumanities). Minnesota: University of Minnesota Press.

Hay Forbes, Norman (I899) Tuberculosis in Cattle - Its Relation to our Meat and Milk Supply: A Lecture to Agriculturalists. Tunbridge Wells: R. Clements.

Henry Rew, R. (I9I4) 'Contemporary Agricultural Law', Journal of the RASE 75.

Horner, J. T. (I909) 'The Milk Supply: From the Distributors Point of View', Journal of the BDFA XXIII. Joyce, Patrick (2003) The Rule of Freedom: Liberalism and the Modern City. London: Verso.

Kendall, Gavin and Mike Michael (I998) 'Order and Disorder: Time, Technology and the Self', Culture Machine I(I): URL (consulted April 2008): http://culturemachine.tees.ac.uk/InterZone/kendall.htm. Latour, Bruno (1983) ‘Give Me a Laboratory and I will Raise the World', pp. I4I-70 in Karin Knorr-Cetina and Michael Mulkay (eds) Science Observed. Beverly Hills and London: Sage.

Latour, Latour (1988) The Pasteurization of France. Cambridge Massachusetts: Harvard University Press. Latour, Bruno (1993) We Have Never been Modern. Harlow: Pearson.

Law, John (2004a) After Method: Mess in Social Science Research, London: Routledge.

Law, John (2004b) Enacting NatureCultures: A Note from STS, Published by the Centre for Science Studies, University of Lancaster, URL (consulted April 2008): http://www.lancs.ac.uk/fass/sociology/ papers/law-enacting-naturecultures.pdf.

Mitchell, Timothy (2002) Rule of Experts: Egypt, Techno-Politics, Modernity. Berkeley: University of California Press.

Mol, Annemarie (1999) 'Ontological Politics: A Word and Some Questions', pp. 74-89 in John Law and John Hassard (eds) Actor Network and After. Oxford \& Keele: Blackwell \& Sociological Review.

Otter, Chris (2006) 'The Vital City: Public Analysis, Dairies and Slaughterhouses in nineteenth-century Britain', Cultural Geographies I3: 5I7-37.

Savage, William G. (I9I7) 'The Protection of the Milk Supply', a lecture delivered at the Royal Institute of Public Health on February 28th I9I7; printed in the June I9I7 Journal of State Medicine; filed as a paper in the Delepine Collection, John Rylands University of Manchester Library.

Sadler, James (I909) 'How to Secure A Milk Supply Free From Tuberculosis - From a Practical Farmer's Point of View', Journal of the BDFA XXIII.

Serpell, James (1996) In the Company of Animals: A Study of Human-Animal Relationships. Cambridge: Cambridge University Press.

Sheldon, J. P. (I909) 'Milk Selling Farmers and Coming Legislation', Journal of the BDFA XXIII.

Waddington, Keir (200I) 'The Science of Cows: Tuberculosis and the State in the United Kingdom, I890-I9I4', History of Science 39, 3(I25): 355-8I.

Waddington, Keir (2004) 'To Stamp Out "So Terrible a Malady": Bovine Tuberculosis and Tuberculin Testing in Britain, I890-I939', Medical History 48(I): 29-48. 
Richie Nimmo is Lecturer in Social Science at the University of Aberdeen. He teaches in social theory and qualitative research methodologies. His current research addresses the problem of the status of nonhumans in social science and modern knowledgepractices more widely, which is explored both theoretically and through historical research on human-animal relations in British dairy farming.

Richie NimMo

Department of Sociology

School of Social Science

Edward Wright Building

King's College

University of Aberdeen

Aberdeen

$\mathrm{AB} 24$ 3QY

United Kingdom

richiejnimmo@aol.com 
0.1 Distinktion_no16 17/04/08 20:16 Side 98

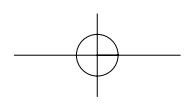

